\title{
ФИЗИОЛОГО-БИОХИМИЧЕСКИЕ КРИТЕРИИ УСТОЙЧИВОСТИ ЯБЛОНИ К АБИОТИЧЕСКИМ СТРЕССАМ ЛЕТНЕГО ПЕРИОДА
}

\author{
Н.И. НЕНЬКО1, Г.К. КИСЕЛЕВА', Е.В. УЛЬЯНОВСКАЯ1, Е.К. ЯБЛОНСКАЯ², \\ A.B. KAPABAEBA ${ }^{1}$
}

В Северо-Кавказском регионе Российской Федерации, где засуха - частое явление, яблоня стала одной из важнейших садовых культур. Физиолого-биохимические исследования необходимы для объективной оценки адаптационной устойчивости сортов яблони к стрессорам летнего периода, в частности к летней засухе. Цель настоящей работы - по физиолого-биохимическим и анатомическим параметрам листа изучить особенности водного режима, фотосинтетической деятельности яблони в условиях летнего периода, а также выделить наиболее засухоустойчивые сорта для возделывания в условиях Северо-Кавказского региона. Исследования проводили в 2011-2013 годах в промышленных плодоносящих насаждениях опытно-производственного хозяйства «Центральное» (г. Краснодар). Объектами исследования служили сорта яблони разного эколого-географического происхождения и плоидности: Айдаред, Эрли Мак, Дейтон (США), Лигол (Польша), Прикубанское, Рассвет, Фортуна, Союз, Родничок (Россия); сорта Союз и Родничок триплоидные, остальные - диплоидные. Для исследований ежемесячно отбирали полностью сформированные листья с трех деревьев (со средней части однолетних приростов) каждого сорта в 3-кратной повторности. Каждая повторность состояла из 10 листьев. Показатели водного режима (оводненность листьев, содержание свободной и связанной форм воды) анализировали весовым методом. Содержание общей воды в листьях определяли после высушивания навесок в термостате при $105{ }^{\circ} \mathrm{C}$ до постоянной массы. Анатомические особенности листовой пластинки изучали на временных препаратах поперечных срезов. У сортов Прикубанское, Фортуна, Союз, Родничок в июле и августе наблюдали уменьшение оводненности в среднем на 1$4 \%$ в сравнении с июнем и самые высокие показатели соотношения связанной и свободной форм воды. У этих же сортов была обнаружена прямая корреляционная связь между площадью листовой пластинки и водообеспеченностью $(r=+0,98)$, отрицательная - между площадью и температурой воздуха $(r=-0,99)$. Водный и температурный режимы влияли на урожайность, а также на закладку плодовых почек, что подтверждалось коэффициентом парной корреляции между суммой хлорофиллов $(\mathrm{a}+\mathrm{b})$ и урожайностью $(r=+0,87)$, оводненностью тканей и закладкой плодовых почек $(r=+0,97)(p \leq 0,05)$. У сортов Прикубанское, Фортуна, Союз, Родничок содержание суммы хлорофиллов было более стабильным в течение летнего периода, а показатель соотношения суммы хлорофиллов и каротиноидов - самым высоким. Выявлена положительная корреляционная связь между содержанием каротиноидов и температурой воздуха $(r=+0,91)(p \leq 0,05)$. В 2012 году у сортов в разной степени проявлялись ксероморфные признаки листовой пластинки, обусловливающие устойчивость к засухе, наибольшие значения индекса палисадности отмечены у сортов Прикубанское, Фортуна, Союз, Родничок $(1,47-1,49)$. Наши результаты согласуются с полевыми данными, полученными в садах без орошения. Таким образом, выявлены особенности перенесения стрессовых факторов летнего периода (высоких температур и засухи) у сортов яблони разного происхождения в условиях Северо-Кавказского региона Российской Федерации. Для сортов Айдаред, Эрли Мак, Дейтон, Лигол характерно пассивное перенесение засухи: уменьшение оводненности, высокое содержание сухого вещества, уменьшение площади листа. У остальных сортов сохранялась высокая оводненность, стабильность ростовых процессов, высокое содержание пигментов. Сорта яблони отечественной селекции обладают большей экологической пластичностью и резервом адаптационного потенциала в сравнении с интродуцированными сортами зарубежной селекции. Выявленные адаптивные особенности этих сортов позволяют вовлекать их в селекционный процесс в качестве источников устойчивости к засухе. Использованные методы дают объективную оценку устойчивости яблони к засухе и могут быть применены в процессе отбора.

Ключевые слова: яблоня, адаптация, засухоустойчивость, оводненность, ксероморфные признаки листовой пластинки, каротиноиды, хлорофилл.

яблоня домашняя (Malus domestica Borkh.) - важная продовольственная культура, под которой занято от 60 до 95 \% возделываемых площадей в различных зонах Северо-Кавказского региона России. Стрессовые

\footnotetext{
* Поддержано грантом №16-44-230077 p_a Российского фонда фундаментальных исследований и администрации Краснодарского края. Дополненная русскоязычная версия англоязычной публикации (Natalia I. Nenko 1 , Galina K. Kisileva, Elena V. Ulianovskaya, Elena K. Yablonskaya, Alla V. Karavaeva. Physiological-biochemical criteria of the apple-tree resistance to the summer period abiotic stresses. Eurasia J. Biosci., 2018, 12: 55-61). Дополнительно представлен массив исходных данных с их расширенной статистической обработкой и анализом. 158
} 
факторы летнего периода, засуха и высокие температуры, негативно влияют на рост и развитие растений яблони, происходит осыпание листьев и плодов, ухудшается закладка генеративных органов, приводящая к снижению урожайности на 15-30 \% (1-3). Стрессовые воздействия вызывают изменения в метаболизме растений, фотосинтезе, водном обмене, что отражается на физиолого-биохимических и анатомо-морфологических показателях (4). Изучение физиолого-биохимических особенностей яблони в нестабильных климатических условиях необходимо для ускорения и повышения эффективности генетико-селекционного процесса и выявления высоко адаптивных сортов в различных зонах садоводства (5-8).

Лист - наиболее пластичный вегетативный орган, реагирующий на изменение экологических факторов (9-11). Особенности водного режима, пигментного комплекса, ксероморфная структуры листа служат надежными критериями засухоустойчивости растений $(12,13)$. В условиях средней полосы России по показателям оводненности тканей, водного дефицита, водоудерживающей способности листьев из 40 сортов и форм яблони выделены генотипы, обладающие наибольшим потенциалом устойчивости к засухе. Установлено, что после теплового шока и завядания колонновидные сорта яблони Кумир, Васюган, Стела теряли от 17,7 до 19,3 \% воды от сырого веса $(14,15)$. В различных почвенно-климатических зонах содержание хлорофиллов и каротиноидов использовали как маркеры засухоустойчивости у плодовых, орехоплодных и декоративных культур (16-20). У фундука с повышением температуры и снижением водообеспеченности уменьшалось содержание хлорофилла и увеличивалось количество каротиноидов в 2 раза (20).

Анатомо-морфологических показателей листа могут быть использованы для выявления засухоустойчивости $(21,22)$, однако требуются дальнейшие исследования связи этих показателей. Опубликованы данные, что у различных сортов груши в условиях субтропиков России при недостаточном водообеспечении уменьшалось число клеток мезофилла, сохранялось соотношение между тканями мезофилла и утолщалась кутикула (23). В других работах, напротив, приводятся данные, что изменение соотношения между тканями мезофилла и уменьшение числа клеток верхнего эпидермиса связаны с засухоустойчивостью персика (24). В условиях Северного Кавказа, характеризующихся специфическими климатическими условиями, прежде всего резкими колебаниями водного и температурного режимов, особенности физиологии засухоустойчивости яблони изучены недостаточно.

В представленной работе впервые использован комплекс физиолого-биохимических и анатомических показателей листовой пластинки для диагностики устойчивости сортов яблони разного эколого-географического происхождения к стрессорам летнего периода в специфических условиях Северного Кавказа. Выявлены особенности перенесения растениями этих сортов высоких температур и засухи.

Цель настоящей работы - по физиолого-биохимическим и анатомическим параметрам листа изучить особенности водного режима, фотосинтетической деятельности яблони в условиях летнего периода, а также выделить наиболее засухоустойчивые сорта для возделывания в условиях Северо-Кавказского региона Российской Федерации.

Методика. Исследования проводили в 2011-2013 годах в промышленных плодоносящих насаждениях опытно-производственного хозяйства «Центральное» (г. Краснодар). Объектами исследования служили сорта яблони разного эколого-географического происхождения: Айдаред, Эрли Мак, Дейтон (США), Лигол (Польша), Прикубанское, Рассвет, Фортуна, 
Союз, Родничок (Россия). Сорта Союз и Родничок были триплоидами, остальные - диплоидами. Сорта Айдаред, Лигол, Прикубанское - 2010 года посадки на подвое СК 4 при схеме посадки 0,9 × 4,5; сорта Рассвет, Фортуна, Союз, Родничок - 2000 года посадки на подвое М 9 (2 × 5); сорта Эрли Мак, Дейтон - 1998 года посадки на подвое М 9 (2 × 5).

Для исследований ежемесячно отбирали полностью сформированные листья с трех деревьев (со средней части однолетних приростов) каждого сорта в 3-кратной биологической повторности. Каждая повторность состояла из 10 листьев. Содержание свободной и связанной форм воды определяли весовым методом (25). Содержание общей воды в листьях определяли путем высушивания навесок в термостате при $105{ }^{\circ} \mathrm{C}$ до постоянной массы. Опыты проводили в 3-кратной аналитической повторности. Анатомические особенности листовой пластинки изучали на временных препаратах поперечных срезов, выполненных бритвой от руки, с применением в качестве вспомогательного средства сердцевины стебля бузины. Срезы без окрашивания и фиксации микроскопировали в капле воды при увеличении $\times 400$ на микроскопе Olympus BX41 («Olympus Corporation», Япония). Биометрические параметры листовой пластинки измеряли с использованием окуляр-микромера в микронах по разработанной методике (26). Содержание пигментов определяли в $85 \%$ ацетоновой вытяжке спектрофотометрически (спектрофотометр Unico 2800, «United Products \& Instruments», США) при $\lambda=663,644,432$ нм (красный светофильтр) (27).

Статистический анализ осуществляли по Б.А. Доспехову (28). Расчеты выполняли с использованием программного пакета Microsoft Excel 2010. Существенность разницы между анализируемыми показателями (НСР05) определяли с достоверной вероятностью $95 \%$, рассчитывали среднее арифметическое $(M)$ и стандартное отклонение $( \pm \mathrm{SD})$. Коэффициент парной корреляции $(r)$ между физиолого-биохимическими показателями рассчитывали при достоверной вероятности $95 \%$.

Результаты. Метеоусловия в зоне проведения исследований существенно различались по годам. В 2011 году засуху отмечали в июле, максимальная температура воздуха достигала $39,5^{\circ} \mathrm{C}$, осадки $-3,1$ мм. В 2012 году период с конца июля до середины августа был аномально жарким и сухим с максимальной температурой воздуха $38,3{ }^{\circ} \mathrm{C}$ (на $4,7{ }^{\circ} \mathrm{C}$ выше нормы), осадки составляли 0,3-0,4 мм (2\% от нормы). В 2013 году наибольшая температура воздуха была $32{ }^{\circ} \mathrm{C}$ (на 1,5-2,5 ${ }^{\circ} \mathrm{C}$ выше нормы), осадки - 35 мм.

Приспособление к условиям культивирования носит комплексный характер и основывается на пластичности анатомических структур, изменении физиолого-биохимических параметров, пределы которых определены конкретным генотипом. Экстремально высокие температуры воздуха и низкая влагообеспеченность отрицательно повлияли на водный режим листового аппарата яблони (29-31).

Значения показателей водного режима сортов яблони значимы при оценке засухоустойчивости сортов. Мы исследовали общую оводненность тканей листа на однолетних приростах и фракционный состав воды. В качестве контроля использовали сорт Айдаред, широко районированный на юге России. У всех сортов оводненность в течение лета изменялась поразному. В июне она составляла 60,53-70,56 \% и зависела от особенностей сорта и метеорологических условий года (табл. 1). В июле и августе, в период наибольшего воздействия стрессовых факторов (особенно в засушливом 2012 году), у сортов Айдаред, Эрли Мак, Дейтон, Лигол отмечали существенное уменьшение оводненности (на 8-14 \%). У остальных сортов 
1. Показатели оводненности (\%) листового аппарата яблони (Malus domestica Borkh.) разных сортов в зависимости от месяца и года (M $\pm \mathrm{SD}$, опытно-производственное хозяйство Щентральное», г. Краснодар)

\begin{tabular}{|c|c|c|c|c|c|c|c|c|c|}
\hline \multirow{2}{*}{ Сорт } & \multicolumn{3}{|c|}{2011 год } & \multicolumn{3}{|c|}{2012 год } & \multicolumn{3}{|c|}{2013 год } \\
\hline & июнь & июль & август & июнь & июль & август & июнь & июль & август \\
\hline Айдаред (контроль) & $69,12 \pm 5,71$ & $59,26 \pm 5,65$ & $58,63 \pm 5,92$ & $68,45 \pm 5,42$ & $57,84 \pm 5,89$ & $58,88 \pm 5,28$ & $69,21 \pm 6,05$ & $58,24 \pm 6,24$ & $57,25 \pm 6,27$ \\
\hline Эрли Мак & $62,54 \pm 5,17$ & $55,87 \pm 5,84$ & $52,41 \pm 4,89$ & $60,53 \pm 3,67$ & $54,76 \pm 3,89$ & $53,78 \pm 3,85$ & $61,25 \pm 4,52$ & $55,89 \pm 4,28$ & $51,29 \pm 4,85$ \\
\hline Дейтон & $65,28 \pm 6,58$ & $54,26 \pm 6,27$ & $52,84 \pm 6,28$ & $64,28 \pm 6,84$ & $53,26 \pm 6,58$ & $52,31 \pm 6,78$ & $66,58 \pm 7,12$ & $55,43 \pm 7,18$ & $52,43 \pm 7,58$ \\
\hline Лигол & $64,32 \pm 4,25$ & $56,24 \pm 4,28$ & $55,61 \pm 4,29$ & $63,53 \pm 5,56$ & $54,28 \pm 5,28$ & $53,72 \pm 5,76$ & $64,23 \pm 4,28$ & $56,27 \pm 4,89$ & $56,87 \pm 4,12$ \\
\hline Прикубанское & $70,56 \pm 0,94$ & $69,27 \pm 1,03$ & $68,71 \pm 0,49$ & $68,57 \pm 0,58$ & $67,53 \pm 0,82$ & $67,58 \pm 0,46$ & $68,75 \pm 0,28$ & $69,12 \pm 0,85$ & $69,58 \pm 0,45$ \\
\hline Рассвет & $67,81 \pm 1,15$ & $65,28 \pm 1,28$ & $65,28 \pm 1,86$ & $66,21 \pm 0,58$ & $65,24 \pm 0,46$ & $65,41 \pm 0,83$ & $68,23 \pm 1,53$ & $65,13 \pm 1,59$ & $66,57 \pm 1,28$ \\
\hline Фортуна & $69,31 \pm 1,25$ & $68,71 \pm 1,48$ & $66,41 \pm 1,46$ & $69,87 \pm 1,49$ & $67,24 \pm 1,27$ & $66,23 \pm 1,53$ & $68,72 \pm 0,48$ & $68,42 \pm 0,27$ & $67,24 \pm 0,46$ \\
\hline Союз & $70,12 \pm 0,86$ & $69,25 \pm 0,78$ & $68,42 \pm 0,49$ & $69,21 \pm 0,58$ & $68,27 \pm 0,58$ & $68,21 \pm 0,27$ & $69,82 \pm 0,78$ & $68,52 \pm 0,58$ & $69,27 \pm 0,46$ \\
\hline Родничок & $70,56 \pm 2,15$ & $69,23 \pm 2,16$ & $66,41 \pm 2,46$ & $68,25 \pm 0,57$ & $68,91 \pm 0,56$ & $67,24 \pm 0,58$ & $69,15 \pm 1,27$ & $69,24 \pm 1,87$ & $66,85 \pm 1,53$ \\
\hline $\mathrm{HCP}_{05}$ & 1,36 & 2,01 & 2,05 & 1,39 & 2,04 & 2,06 & 1,32 & 1,96 & 2,13 \\
\hline
\end{tabular}

2. Пигментный состав (мг/г сухого вещества) листьев яблони (Malus domestica Borkh.) разных сортов в летний период 2011-2013 годов ( $M \pm \mathrm{SD}$, опытно-производственное хозяйство «ентральное», г. Краснодар)

\begin{tabular}{|c|c|c|c|c|c|c|c|c|c|}
\hline \multirow{2}{*}{ Сорт } & \multicolumn{3}{|c|}{2011} & \multicolumn{3}{|c|}{2012} & \multicolumn{3}{|c|}{2013} \\
\hline & $(a+b)$ & $\mathrm{K}$ & $(a+b) / K$ & $(a+b)$ & $\mathrm{K}$ & $(a+b) / K$ & $(a+b)$ & $\mathrm{K}$ & $(a+b) / K$ \\
\hline Айдаред (контроль) & $4,72 \pm 0,42$ & $1,04 \pm 0,07$ & $4,54 \pm 0,41$ & $5,12 \pm 0,49$ & $0,96 \pm 0,08$ & $5,33 \pm 0,19$ & $4,22 \pm 0,46$ & $0,90 \pm 0,09$ & $4,68 \pm 0,42$ \\
\hline Эрли Мак & $4,22 \pm 0,13$ & $1,24 \pm 0,01$ & $3,40 \pm 0,24$ & $4,42 \pm 0,18$ & $1,24 \pm 0,02$ & $3,56 \pm 1,33$ & $4,16 \pm 0,28$ & $1,42 \pm 0,07$ & $2,92 \pm 0,34$ \\
\hline Дейтон & $4,82 \pm 0,12$ & $1,22 \pm 0,08$ & $3,95 \pm 0,35$ & $4,96 \pm 0,28$ & $1,20 \pm 0,02$ & $4,13 \pm 0,12$ & $4,72 \pm 0,24$ & $1,20 \pm 0,08$ & $3,93 \pm 0,12$ \\
\hline Лигол & $4,70 \pm 0,34$ & $1,28 \pm 0,23$ & $3,67 \pm 0,28$ & $5,02 \pm 0,35$ & $1,22 \pm 0,51$ & $4,11 \pm 0,17$ & $4,42 \pm 0,28$ & $1,36 \pm 0,02$ & $3,25 \pm 0,43$ \\
\hline Прикубанское & $5,38 \pm 0,12$ & $0,96 \pm 0,05$ & $5,60 \pm 0,75$ & $5,51 \pm 0,28$ & $0,96 \pm 0,28$ & $5,72 \pm 0,10$ & $5,62 \pm 0,21$ & $1,02 \pm 0,07$ & $5,51 \pm 0,10$ \\
\hline Рассвет & $4,70 \pm 0,50$ & $1,02 \pm 0,08$ & $4,60 \pm 0,25$ & $5,62 \pm 0,49$ & $1,18 \pm 0,05$ & $4,76 \pm 0,14$ & $5,50 \pm 0,78$ & $1,16 \pm 0,03$ & $4,74 \pm 0,41$ \\
\hline Фортуна & $5,36 \pm 0,05$ & $0,90 \pm 0,05$ & $5,95 \pm 0,24$ & $5,44 \pm 0,02$ & $0,86 \pm 0,02$ & $6,32 \pm 0,28$ & $5,28 \pm 0,05$ & $0,96 \pm 0,04$ & $5,50 \pm 0,42$ \\
\hline Союз & $5,32 \pm 0,11$ & $0,96 \pm 0,06$ & $5,54 \pm 0,46$ & $5,46 \pm 0,12$ & $0,92 \pm 0,08$ & $5,93 \pm 0,44$ & $5,22 \pm 0,16$ & $0,92 \pm 0,04$ & $5,67 \pm 0,19$ \\
\hline Родничок & $5,58 \pm 0,04$ & $0,91 \pm 0,09$ & $6,13 \pm 0,57$ & $5,66 \pm 0,05$ & $0,84 \pm 0,04$ & $6,73 \pm 0,19$ & $5,62 \pm 0,02$ & $0,96 \pm 0,03$ & $5,85 \pm 0,42$ \\
\hline $\mathrm{HCP}_{05}$ & 0,34 & 0,22 & 0,41 & 0,25 & 0,24 & 0,51 & 0,27 & 0,28 & 0,45 \\
\hline
\end{tabular}




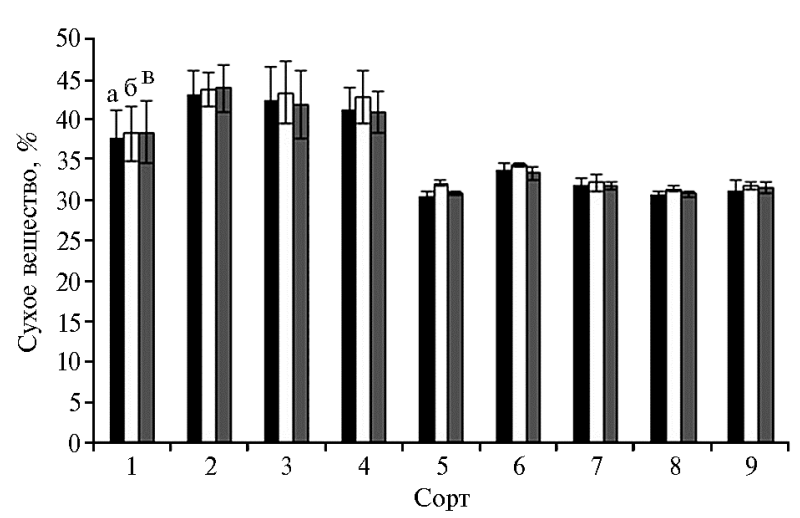

Рис. 1. Среднее содержание сухих веществ в листьях яблони (Malus domestica Borkh.) разных сортов в течение летнего периода 2011 (а), 2012 (б) и 2013 года (в): 1 Айдаред, 2 - Эрли Мак, 3 - Дейтон, 4 - Лигол, 5 Прикубанское, 6 - Рассвет, 7 - Фортуна, 8 - Союз, $9-$ Родничок. НСР05: а $-0,89$; б - 0,68; в - 0,81 (опытнопроизводственное хозяйство «Центральное», г. Краснодар). оводненность листовых тканей уменьшилась в среднем на 1-4 \%. Наибольшее снижение этого показателя у сортов Айдаред, Эрли Мак, Дейтон, Лигол в августе сопровождалось усилением синтетических процессов и накоплением сухих веществ в тканях листа до $48,71 \%$ (в 2012 году - до 47,69\%) (рис. 1). У других сортов содержание сухих веществ составляло от $29,44 \%$ в июне до $34,87 \%$ - в августе.

Показателем устойчивости растений к низкой влагообеспеченности и засухе служит соотношение свя-

занной и свободной форм воды (Ксвяз.своб.). Связанная форма воды обеспечивает водоудерживающую способность клетки. Высокий коэффициент количественного соотношения связанной и свободной воды свидетельствует о высокой засухоустойчивости сорта.

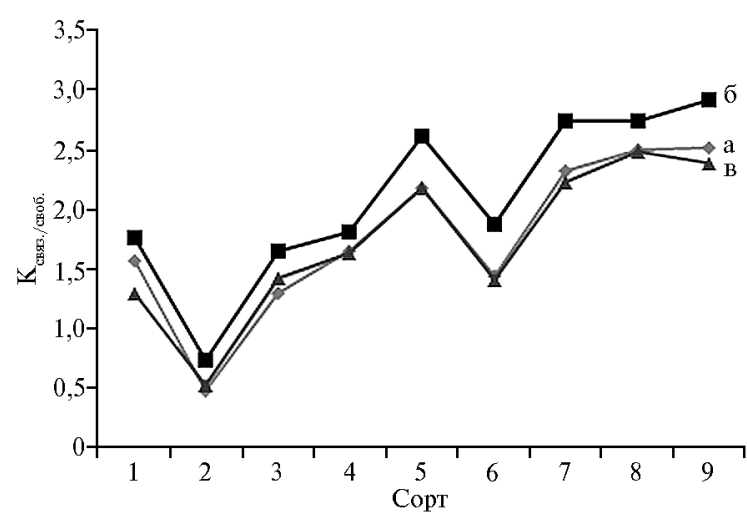

Рис. 2. Соотношение связанной и свободной форм воды (Ксвяз./своб.) в листьях яблони (Malus domestica Borkh.) разных сортов в течение летнего периода 2011 (а), 2012 (б) и 2013 года (в): 1 - Айдаред, 2 - Эрли Мак, 3 - Дейтон, 4 - Лигол, 5 - Прикубанское, 6 Рассвет, 7 - Фортуна, 8 - Союз, $9-$ Родничок. НСР05: а - 0,54; б - 0,58; в - 0,61 (опытнопроизводственное хозяйство «Центральное», г. Краснодар).

У сортов Прикубанское, Фортуна, Союз, Родничок отмечались самые высокие значения К Квяз./своб. - от 2,06 до 2,61 в 2011 и 2013 годах (рис. 2). В засушливый 2012 год этот показатель у всех сортов был выше, чем в 2011 и 2013 годах и варьировал в пределах 1,53-2,99. У сорта Эрли Мак в течение вегетационного

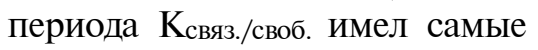
низкие значения $0,41-0,82$, что свидетельствует о низкой устойчивости к стресс-факторам летнего периода.

Физиологическое состояние растений наилучшим образом характеризуется увеличением площади листовой пластинки. По данным литературы, в периоды с недостаточной влагообеспеченностью площадь листа снижалась у сортов смородины красной, манго $(32,33)$, а у миндаля, напротив, не изменялась (34). В наших исследованиях линейные параметры листа в течение вегетационного периода зависели от сортовой принадлежности и гидротермических условий года. Так, у сортов Айдаред, Эрли Мак, Дейтон, Лигол площадь листовой пластинки уменьшалась в наиболее засушливый 2012 год и составляла в среднем 68,29 см² (в 2011 году в среднем 72,52 см²) (рис. 3).

У остальных сортов изменения в размерах листа были незначитель- 
ными. Мы выявили прямую корреляцию между площадью листовой пластинки и водообеспеченностью $(r=+0,98)$, отрицательную - между площадью и температурой воздуха $(r=-0,99)(\mathrm{p} \leq 0,05)$. Водный и температурный режимы влияют на урожайность, а также на закладку плодовых почек, определяющих урожай следующего года, воздействуют на функциональное состояние ассимиляционного аппарата, что подтверждалось коэффициентом парной корреляции между суммой хлорофиллов и урожайностью $(r=+0,87)$, оводненностью тканей и закладкой плодовых почек $(r=+0,97)$ $(\mathrm{p} \leq 0,05)$.

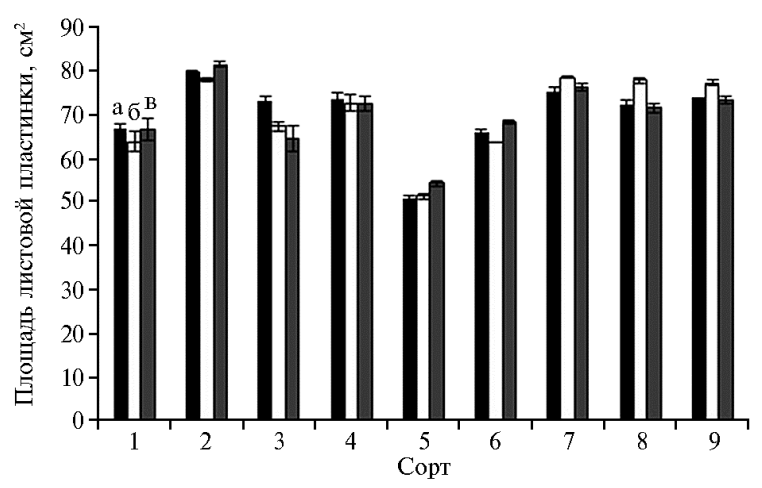

Рис. 3. Средняя площадь листовой пластинки у растений яблони (Malus domestica Borkh.) разных сортов в течение летнего периода 2011 (а), 2012 (б) и 2013 года (в): 1 - Айдаред, 2 - Эрли Мак, 3 - Дейтон, 4 Лигол, 5 - Прикубанское, 6 - Рассвет, 7 - Фортуна, 8 - Союз, 9 - Родничок. НСР05: а - 0,65, б - 0,51, в - 0,51 (опытно-производственное хозяйство «Центральное», г. Краснодар).

Засуха и повышенные температуры воздуха влияют также на пигментный состав листьев $(35,36)$, что подтверждалось и нашими исследованиями. Соотношение содержания суммы хлорофиллов $(\mathrm{a}+\mathrm{b})$ и каротиноидов в листьях у изучаемых сортов яблони в течение лета изменялось по-разному. У сортов Союз, Прикубанское, Фортуна, Родничок сумма хлорофиллов была более стабильным в течение летнего периода, а в июле-августе отмечали усиленное накопление каротиноидов, что подтверждалось положительной корреляционной связью между содержанием каротиноидов и температурой воздуха $(r=+0,91)$ $(\mathrm{p} \leq 0,05)$. Каротиноиды, обладая антиоксидантными свойствами, играют важную роль в защитных реакциях растений. Их повышенное накопление в неблагоприятных условиях летнего периода необходимо для стимулирования адаптивных реакций и снижения общего стресса. Наиболее информативным показателем служит количественное соотношение суммы хлорофиллов и каротиноидов, отражающее степень приспособленности растений к неблагоприятным факторам среды. У всех сортов этот показатель имел наибольшие значения в 2012 году. У сортов Прикубанское, Фортуна, Союз, Родничок соотношение суммы хлорофиллов и каротиноидов оказалось выше (5,72-6,73), чем у других. В 2011 и 2013 годах анализируемый показатель составлял 5,50-6,13 (табл. 2).

По состоянию водного режима и пигментного комплекса наибольшую устойчивость к засушливым условиям проявляли сорта отечественной селекции Прикубанское, Фортуна, Союз, Родничок.

Изменения физиологических процессов влияют на анатомо-мофологическое строение листа. Лист яблони дорзовентральный, мезофилл дифференцирован на палисадную и столбчатую ткани. Палисадная ткань состоит из двух слоев клеток. Устьичный аппарат аномоцитного типа, устьица сосредоточены на абаксиальной стороне листовых пластинок. Анатомоморфологическая структура листа имела сортовые особенности, а также зависела от температуры и водообеспеченности. У триплоидных сортов Союз и Родничок клетки листа были крупнее, чем у остальных изученных сортов, а толщина листовой пластинки имела максимальные размеры. В засушливый 2012 год у всех сортов, кроме Эрли Мак, в разной степени про- 
3. Анатомо-морфологические параметры (мкм) листовой пластинки у растений яблони (Malus domestica Borkh.) разных сортов в летний период 2011-2013 годов ( $M \pm \mathrm{SD}$, опытно-производственное хозяйство «Центральное», г. Краснодар)

\begin{tabular}{|c|c|c|c|c|c|c|c|c|c|}
\hline \multirow{2}{*}{ Сорт } & \multicolumn{3}{|c|}{2011} & \multicolumn{3}{|c|}{2012} & \multicolumn{3}{|c|}{2013} \\
\hline & ОТЛ & КЭ & ИП & ОТЛ & КЭ & ИП & ОТЛ & КЭ & ИП \\
\hline Айдаред (контроль) & $176,2 \pm 2,65$ & $10,0 \pm 0,12$ & $1,27 \pm 0,01$ & $180,3 \pm 2,34$ & $10,2 \pm 0,12$ & $1,30 \pm 0,01$ & $175,4 \pm 2,34$ & $10,0 \pm 0,12$ & $1,29 \pm 0,01$ \\
\hline Эрли Мак & $171,5 \pm 0,17$ & $9,1 \pm 0,01$ & $1,01 \pm 0,01$ & $171,5 \pm 0,18$ & $9,1 \pm 0,01$ & $1,01 \pm 0,01$ & $171,2 \pm 0,27$ & $9,1 \pm 0,02$ & $1,01 \pm 0,01$ \\
\hline Дейтон & $191,3 \pm 3,75$ & $10,1 \pm 0,23$ & $1,28 \pm 0,01$ & $198,5 \pm 3,45$ & $10,5 \pm 0,23$ & $1,29 \pm 0,01$ & $192,8 \pm 3,57$ & $10,1 \pm 0,21$ & $1,28 \pm 0,01$ \\
\hline Лигол & $163,8 \pm 4,12$ & $10,2 \pm 0,10$ & $1,30 \pm 0,01$ & $170,2 \pm 4,15$ & $10,4 \pm 0,10$ & $1,32 \pm 0,01$ & $162,3 \pm 4,17$ & $10,3 \pm 0,12$ & $1,30 \pm 0,01$ \\
\hline Прикубанское & $199,2 \pm 3,45$ & $11,2 \pm 0,21$ & $1,47 \pm 0,01$ & $205,3 \pm 3,48$ & $11,5 \pm 0,19$ & $1,49 \pm 0,01$ & $199,5 \pm 3,27$ & $11,1 \pm 0,21$ & $1,46 \pm 0,01$ \\
\hline Ррассвет & $169,4 \pm 3,12$ & $10,3 \pm 0,05$ & $1,32 \pm 0,02$ & $175,4 \pm 3,27$ & $10,3 \pm 0,05$ & $1,35 \pm 0,02$ & $170,7 \pm 3,17$ & $10,2 \pm 0,03$ & $1,31 \pm 0,02$ \\
\hline Фортуна & $178,5 \pm 2,81$ & $11,1 \pm 0,10$ & $1,46 \pm 0,01$ & $181,4 \pm 2,47$ & $11,3 \pm 0,11$ & $1,47 \pm 0,02$ & $175,6 \pm 2,42$ & $11,2 \pm 0,13$ & $1,45 \pm 0,01$ \\
\hline Союз & $213,9 \pm 15,23$ & $11,2 \pm 0,12$ & $1,45 \pm 0,01$ & $243,6 \pm 15,21$ & $11,4 \pm 0,15$ & $1,48 \pm 0,01$ & $221,3 \pm 14,27$ & $11,1 \pm 0,17$ & $1,46 \pm 0,01$ \\
\hline Родничок & $215,4 \pm 14,21$ & $11,2 \pm 0,24$ & $1,45 \pm 0,01$ & $241,5 \pm 13,78$ & $11,6 \pm 0,25$ & $1,48 \pm 0,01$ & $216,1 \pm 11,24$ & $11,2 \pm 0,24$ & $1,46 \pm 0,01$ \\
\hline$\underline{\mathrm{HCP}} 05$ & 3,46 & 0,67 & 0,30 & 4,21 & 0,71 & 0,31 & 3,63 & 0,67 & 0,30 \\
\hline
\end{tabular}

4. Характеристики устьичного аппарата (число устьиц и размеры замыкающих клеток) у растений яблони (Malus domestica Borkh.) разных сортов в летний период 2011-2013 годов $(M \pm \mathrm{SD}$, опытно-производственное хозяйство «Центральное», г. Краснодар)

\begin{tabular}{|c|c|c|c|c|c|c|c|c|c|}
\hline \multirow{2}{*}{ Сорт } & \multicolumn{3}{|c|}{2011} & \multicolumn{3}{|c|}{2012} & \multicolumn{3}{|c|}{2013} \\
\hline & число, шт. & ширина, мкм & длина, мкм & число, шт. & ширина, мкм & длина, мКм & число, шт. & ширина, мкм & длина, мкм \\
\hline Айдаред (контроль) & $215,1 \pm 1,12$ & $31,1 \pm 0,54$ & $54,4 \pm 0,41$ & $216,5 \pm 1,25$ & $32,1 \pm 0,64$ & $55,2 \pm 0,42$ & $217,5 \pm 1,24$ & $32,2 \pm 0,58$ & $54,9 \pm 0,43$ \\
\hline Эрли Мак & $189,4 \pm 0,15$ & $34,0 \pm 0,04$ & $56,2 \pm 0,52$ & $189,7 \pm 0,14$ & $34,1 \pm 0,07$ & $55,6 \pm 0,51$ & $189,5 \pm 0,27$ & $34,1 \pm 0,02$ & $55,2 \pm 0,49$ \\
\hline Дейтон & $245,2 \pm 0,84$ & $31,0 \pm 0,23$ & $54,8 \pm 0,24$ & $245,8 \pm 0,84$ & $31,3 \pm 0,19$ & $54,4 \pm 0,21$ & $244,2 \pm 0,71$ & $31,4 \pm 0,24$ & $54,4 \pm 0,26$ \\
\hline Лигол & $231,6 \pm 0,46$ & $32,1 \pm 0,21$ & $54,2 \pm 0,10$ & $232,4 \pm 0,42$ & $31,7 \pm 0,18$ & $54,3 \pm 0,12$ & $231,60,43 \pm$ & $31,8 \pm 0,17$ & $54,4 \pm 0,12$ \\
\hline Прикубанское & $270,4 \pm 3,87$ & $30,1 \pm 0,27$ & $53,7 \pm 0,25$ & $275,3 \pm 3,57$ & $30,2 \pm 0,22$ & $53,6 \pm 0,25$ & $267,4 \pm 3,84$ & $30,5 \pm 0,16$ & $53,2 \pm 0,27$ \\
\hline Рассвет & $236,7 \pm 1,02$ & $31,7 \pm 0,17$ & $54,3 \pm 0,31$ & $237,4 \pm 1,01$ & $31,4 \pm 0,17$ & $54,7 \pm 0,34$ & $235,4 \pm 1,04$ & $31,4 \pm 0,18$ & $54,1 \pm 0,31$ \\
\hline Фортуна & $265,3 \pm 2,34$ & $31,0 \pm 0,27$ & $53,2 \pm 0,42$ & $270,6 \pm 2,54$ & $31,5 \pm 0,42$ & $53,8 \pm 0,42$ & $267,3 \pm 2,47$ & $30,6 \pm 0,42$ & $54,0 \pm 0,42$ \\
\hline Сою3 & $281,4 \pm 5,13$ & $30,1 \pm 0,24$ & $53,2 \pm 0,58$ & $289,7 \pm 5,24$ & $30,6 \pm 0,24$ & $53,2 \pm 0,56$ & $280,4 \pm 5,27$ & $30,4 \pm 0,22$ & $54,2 \pm 0,54$ \\
\hline Родничок & $284,7 \pm 2,14$ & $30,2 \pm 0,57$ & $53,1 \pm 0,04$ & $289,3 \pm 2,47$ & $30,8 \pm 0,39$ & $53,1 \pm 0,04$ & $284,6 \pm 2,37$ & $30,1 \pm 0,34$ & $53,0 \pm 0,58$ \\
\hline $\mathrm{HCP} 05$ & 4,34 & 0,89 & 0,79 & 4,50 & 0,84 & 0,70 & 4,33 & 0,87 & 0,64 \\
\hline
\end{tabular}


являлись ксероморфные признаки, обусловливающие устойчивость к засухе: увеличение толщины листовой пластинки, кутикулы, индекса палисадности, числа устьиц на единицу листовой поверхности, уменьшение линейных размеров устьиц.

Индекс палисадности (соотношение толщины палисадного и губчатого слоев) - наиболее информативный показатель, определяющий устойчивость к засухе. В 2012 году он повышался у всех сортов, наибольшие его значения отмечали у сортов Прикубанское, Фортуна, Союз, Родничок $(1,47-1,49)$, выделенных как высокозасухоустойчивые. Сорта Айдаред, Дейтон, Лигол, Рассвет с индексом палисадности 1,27-1,35 считались засухоустойчивыми, сорт Эрли Мак $(1,01)$ - незасухоустойчивым (табл. 3).

В некоторых исследованиях выявлена связь между водообеспеченностью и количеством устьиц на единицу листовой поверхности. В условиях влажных субтропиков России число и размер устьиц груши изменялись в зависимости от условий вегетации: в годы с обильными осадками в период активного роста побегов и листьев плотность размещения устьиц уменьшалась при увеличении их размеров, в засушливые годы происходили обратные процессы (23). В исследованиях китайских ученых сорта персика с высокой плотностью расположения устьиц обладали повышенной засухоустойчивостью (24). В других работах подобной зависимости не обнаружено. Так, водообеспеченность не оказала существенного влияния на плотность устьиц у молодых растений миндаля (34). По нашим данным, для засухоустойчивых сортов характерно увеличение количества устьиц на единицу листовой поверхности и уменьшение размеров замыкающих клеток в сравнении с неустойчивыми сортами (табл. 4). Так, у сортов Прику-

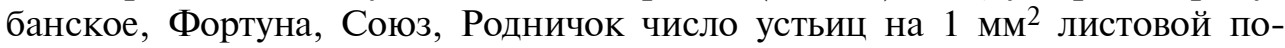
верхности варьировало от 265,3 до 289,7 шт. У остальных изученных сортов оно составляло 189,4-245,8 шт. Максимальные длину и ширину устьиц (соответственно 56,2 и 34,1 мкм) отмечали у незасухоустойчивого сорта Эрли Мак, минимальные (53,2 и 30,1 мкм) - у высокозасухоустойчивого сорта Союз. Полученные результаты согласовывались с полученными в полевых испытаний в садах без орошения (данные не представлены).

Таким образом, на основании оценки устойчивости растений к жаре и засухе по комплексу физиолого-биохимических и анатомических параметров выявлены особенности перенесения стрессовых факторов летнего периода (высоких температур и низкой влагообеспеченности) у сортов яблони разного эколого-географического происхождения в условиях Северо-Кавказского региона России. Установлено, что для сортов-интродуцентов Айдаред, Эрли Мак, Дейтон, Лигол характерно пассивное перенесение засухи: уменьшение оводненности, высокое содержание сухого вещества, уменьшение площади листа. У сортов отечественной селекции сохраняется высокая оводненность, стабильность ростовых и синтетических процессов, высокое содержание пигментов. Сорта яблони отечественной селекции Прикубанское, Фортуна, Союз, Родничок обладают большей экологической пластичностью и резервом адаптационного потенциала, чем интродуцированные сорта зарубежной селекции. Выявленные адаптационные особенности сортов яблони позволяют вовлекать их в селекционный процесс в качестве источников засухоустойчивости. Примененные нами методы дают объективную оценку устойчивости яблони к засухе и могут быть использованы в селекционном процессе.

\section{Л ИТ Е РАТ УРА}

1. Ульяновская Е.В., Супрун И.И., Токмаков С.В., Ушакова Я.В. Комплексный подход к 
отбору ценных генотипов яблони, устойчивых к стрессовым факторам среды. Плодоводство и виноградарство Юга России, 2014, 25(01): 11-26.

2. Tworkoski T., Fazio G., Glenn D.M. Apple rootstock resistance to drought. Scientia Horticulturae, 2016, 204: 70-78 (doi: 10.1016/j.scienta.2016.01.047).

3. Alizadeh A., Alizade V., Nassery L., Eivazi A. Effect of drought stress on apple dwarf rootstocks. Technical Journal of Engineering and Applied Science, 2011, 1(3): 86-94.

4. Wahid A., Gelani S., Ashraf M., Foolad M. Heat tolerance in plants: An overview. Environ. Exp. Bot., 2007, 61(3): 199-223 (doi: 10.1016/j.envexpbot.2007.05.011).

5. Жученко А.А. Настоящее и будущее адаптивной системы селекции и семеноводства растений на основе идентификации и систематизации их генетических ресурсов. Сельскохозяйственная биология, 2012, 5: 3-19.

6. Belous O.G., Klemeshova K.V., Pashchenko O.I. Comparative analysis of photosynthetic indicators in freesia hybrids on the Black sea coast of Krasnodar region. Horticultural Science, 2017, 44(2): 99-104 (doi: 10.17221/189/2015-HORTSCI).

7. Henfrey J.L., Baab G., Schmitz M. Physiological stress responses in apple under replant conditions. Scientia Horticulturae, 2015, 194: 111-117 (doi: 10.1016/j.scienta.2015.07.034).

8. Маляровская В.И., Белоус О.Г. Изучение физиологических показателей вейгелы (Weigela $\times$ wagneri L.H. Bailey), характеризующих ее устойчивость к стресс-факторам влажных субтропиков России. Садоводство и виноградарство, 2016, 5: 46-51 (doi: 10.18454/vstisp.2016.5.3449).

9. Bassett C.L., Glenn D.M., Forsline P.L., Wisniewski M.E., Farrell R.E. Jr. Characterizing water use efficiency and water deficit responses in apple (Malus $\times$ domestica Borkh. and Malus sieversii Ledeb.) M. Roem. Horticultural Science, 2011, 46(8): 1079-1984 (doi: 10.21273/HORTSCI.46.8.1079).

10. Liu Z.C., Bao D.E. Effect of water stress on growth and physiological indexes in Jinguang plum seedlings. Journal of Agricultural University of Hebei, 2007, 30(5): 28-31.

11. Wang S., Liang D., Li C., Hao Y., Ma F., Shu H. Influence of drought stress on the cellular ultrastructure and antioxidant system in leaves of drought-tolerant and drought-sensitive apple rootstocks. Plant Physiol. Biochem., 2012, 51:81-89 (doi: 10.1016/j.plaphy.2011.10.014).

12. Рындин А.В., Белоус О.Г. Устойчивость растений чая в условиях субтропиков России: диагностика и способы повышения. Сельскохозяйственная биология, 2008, 3: 78-82.

13. Serra I., Strever A., Myburgh P.A., Deloire A. Review: the interaction between rootstocks and cultivars (Vitis vinifera L.) to enhance drought tolerance in grapevine. Aust. J. Grape Wine Res., 2014, 20: 1-14 (doi: 10.1111/ajgw.12054).

14. Савельева И.Н., Савельева Н.Н. Засухоустойчивость колонновидных сортов и форм яблони. Вестник Мичуринского государственного аграрного университета, 2011, 2(1): 36-38.

15. Савельев Н.И., Юшков А.Н., Чивилев В.В., Савельева Н.Н., Борзых Н.В., Земисов А.С., Хожайнов А.В., Савельева И.Н. Потенциал устойчивости семечковых культур к высокотемпературным стрессам. Плодоводство и ягодоводство России, 2012, 29(2): 147-152.

16. Тыщенко Е.Л., Тимкина Ю.В., Киселева Г.К. Адаптационный потенциал гибискуса сирийского при интродукции в центральной подзоне Краснодарского края. Плодоводство $u$ виноградарство Юга России, 2010, 3: 20-28.

17. Šircelj H., Tausz M., Grill D., Batič F. Biochemical responses in leaves of two apple tree cultivars subjected to progressing drought. J. Plant Physiol., 2005, 162(12): 1308-1318 (doi: 10.1016/j.jplph.2005.01.018).

18. Šircelj H., Tausz M., Grill D., Batič F. Detecting different levels of drought stress in apple trees (Malus domestica Borkh.) with selected biochemical and physiological parameters. Scientia Horticulturae, 2007, 113(4): 362-369 (doi: 10.1016/j.scienta.2007.04.012).

19. Larsen F.E, Higgins S.S, Al Wir A. Diurnal water relations of apple, apricot, grape, olive and peach in an arid environment (Jordan). Scientia Horticulturae, 1989, 39(3): 211-222 (doi: 10.1016/0304-4238(89)90134-9).

20. Рындин А.В., Белоус О.Г., Маляровская В.И., Притула 3.В., Абильфазова Ю.С., Кожевникова А.М. Использование физиолого-биохимических методов для выявления механизмов адаптации субтропических, южных плодовых и декоративных культур в условиях субтропиков России. Сельскохозяйственная биология, 2014, 3: 40-48 (doi: 10.15389/agrobiology.2014.3.40rus).

21. Беседина Т.Д., Смагин Н.Е., Добежина С.В. Адаптивный потенциал сортов персика, возделываемых во влажных субтропиках России. Вестник АПК Ставрополья, 2017, 1(25): $123-129$.

22. Banowetz G.M., Azevedo M.D., Stout R. Morphological adaptations of hot springs panic grass (Dichanthelium lanigunosum var sericeum (Schmoll) to thermal stress. J. Therm. Biol., 2008, 33(2): 106-116 (doi: 10.1016/j.jtherbio.2007.08.006).

23. Киселева Н.С. Оценка адаптационной способности различных генотипов груши по морфоанатомическому и физиологическому состоянию листьев. Сельскохозяйственная биология, 2009, 3: 34-38. 
24. Meng Q.-J., Wang G.-Q., Dong S.-F., Zhang L., Gong Z.-D. Relation between leaf tissue parameters and drought resistance of peaches. Agricultural Research in the Arid Areas, 2004, 22(3): 123-126.

25. Кушниренко М.Д., Печерская С.Н. Физиология водообмена и засухоустойчивости растений. Кишинев, 1991.

26. Хржановский В.Г., Пономаренко С.Ф. Практикум по курсу общей ботаники. М., 1989.

27. Гавриленко В.Ф., Ладыгина М.Е., Хандобина Л.М. Большой практикум по физиологии растений. М., 1975.

28. Доспехов Б.А. Методика полевого опыта (с основами статистической обработки результатов исследований). М., 1979.

29. Massonnet C., Costes E., Rambal S., Dreyer E., Regnard J.L. Stomatal regulation of photosynthesis in apple leaves: evidence for different water-use strategies between two cultivars. Annals of Botany, 2007, 100(6): 1347-1356 (doi: 10.1093/aob/mcm222).

30. Ненько Н.И., Сундырева М.А. Водный режим листьев винограда в стрессовых условиях периода вегетации. Виноделие и виноградарство, 2012, 1: 38-42.

31. Jones H.G., Serraj R., Loveys B.R., Xiong L., Wheaton A., Adam H., Price A.H. Thermal infrared imaging of crop canopies for the remote diagnosis and quantification of plant responses to water stress in the field. Funct. Plant Biol., 2005, 36(11): 978-989 (doi: 10.1071/FP09123).

32. Панфилова О.В., Голяева О.Д. Физиологические особенности адаптации сортов и отборных форм смородины красной к засухе и повышенным температурам. Сельскохозяйственная биология, 2017, 52(5): 1056-1064 (doi: 10.15389/agrobiology.2017.5.1056rus).

33. Zaharah S.S., Razi I.M. Growth, stomata aperture, biochemical changes and branch anatomy in mango (Mangifera indica) cv. Chokanan in response to root restriction and water stress. Scientia Horticulturae, 2009, 123(1): 58-67 (doi: 10.1016/j.scienta.2009.07.022).

34. Yadollahi A., Arzani K., Ebadi A., Wirthensohn M., Karimi S. The response of different almond genotypes to moderate and severe water stress in order to screen for drought tolerance. Scientia Horticulturae, 2011, 129(3): 403-413 (doi: 10.1016/j.scienta.2011.04.007).

35. Mierowska A., Keutgen N., Huysamer M., Smith V. Photosynthetic acclimation of apples spur leaves to summer-pruning. Scientia Horticulturae, 2002, 92(1): 9-27 (doi: 10.1016/S03044238(01)00275-8).

36. Reddy A.R., Chaitanya K.V., Vivekanandan M. Drought-induced responses of photosynthesis and antioxidant metabolism in higher plants (review). J. Plant Physiol., 2004, 161(11): 11891202 (doi: 10.1016/j.jplph.2004.01.013).

\title{
1 ФГБНУ Северо-Кавказский федеральный научный центр Поступила в редакцию садоводства, виноградарства, виноделия, 11 июля 2018 года
}

350901 Россия, г. Краснодар, ул. 40 лет Победы, 39, e-mail: nenko.nataliya@yandex.ru $\bowtie$, galina-kiseleva-1960@mail.ru, alla.karavaeva.65@mail.ru, kubansad@kubannet.ru;

2ФГБНУ ВО Кубанский государственный аграрный университет им. И.Т. Трубилина,

350044 Россия, г. Краснодар, ул. Калинина, 13,

e-mail: yablonskay@mail.ru

Sel'skokhozyaistvennaya biologiya [AgriculturalBiology], 2019, V. 54, № 1, pp. 158-168

\section{PHYSIO-BIOCHEMICAL CRITERIA FOR APPLE TREE TOLERANCE TO SUMMER ABIOTIC STRESSES}

\author{
N.I. Nenko', G.K. Kiseleva1 , E.V. Ulyanovskaya ${ }^{1}$, E.K. Yablonskaya ${ }^{2}$, A.V. Karavayeva1
}

\begin{abstract}
${ }^{1}$ North Caucasian Federal Scientific Center of Horticulture, Viticulture, Wine-making, 39, ul. im. 40-letiya Pobedy, Krasnodar, 350901 Russia, e-mail nenko.nataliya@yandex.ru ( $₫$ corresponding author), galina-kiseleva-1960@mail.ru, alla.karavaeva.65@mail.ru,kubansad@kubannet.ru;

2Trubilin Kuban State Agrarian University, 13, ul. Kalinina, Krasnodar, 350044 Russia, e-mail yablonskay@mail.ru ORCID:

Nenko N.I. orcid.org/0000-0003-4295-3363

Kiseleva G.K. orcid.org/0000-0001-7583-1261

Ulyanovskaya E.V. orcid.org/0000-0003-3987-7363

The authors declare no conflict of interests

Acknowledgements:

Supported financially by grant No. 16-44-230077 p_a from Russian Foundation for Basic Research and by Administration of Krasnodar Krai

Received July 11, 2018

Yablonskaya E.K. orcid.org/0000-0003-1043-5879

Karavayeva A.V. orcid.org/0000-0001-6531-309X
\end{abstract}

\begin{abstract}
In Russia's North Caucasus where drought is frequent the apple tree is one of the most im-
\end{abstract}


portant garden crops. Physiological and biochemical studies are necessary to assess adaptiveness of apple varieties to stressors during summer, in particular, to summer drought. The purpose of this work is to study physiological, biochemical and anatomical parameters of leaves to assess the water regime, photosynthetic activity of apple trees in summer conditions, and to identify the most drought tolerant varieties for cultivation in the North Caucasus region. Research was carried out in 20112013 in fruit-bearing plantations (Central'noe Farm, Krasnodar) on apple varieties of different ecogeographical origin and ploidy: Idared, Earle Mack, Dayton (United States), Ligol (Poland), Prikubanskoe, Rassvet, Fortuna, Soyuz, Rodnichok (Russia). Varieties Soyuz and Rodnichok are triploids, the rest ones are diploids. Monthly, fully formed leaves were collected from (from the middle part of annual shoots of three trees in 3 replicates for each variety, 10 leaves per replicate. Indicators of water regime (total, free and bound water contents) were analyzed gravimetrically. The total water was determined after drying samples at $105{ }^{\circ} \mathrm{C}$ to a constant weight. For anatomical examinations, leaf blade transverse sections (temporary preparations) were used. It was shown that the leaf tissue water content, as well as the ratio of the bound and free water depend on both the variety specificity and the meteorological conditions of the year. Leaf water content in Prikubanskoe, Fortuna, Soyuz, and Rodnichok trees during July and August decreased by an average of 1-4\% compared to June, and the bound-to-free water ratio was the highest. Also, direct correlation between the leaf area and water availability $(r=+0.98)$, and negative correlation between the leaf area and air temperature $(r=-0.99$, $(\mathrm{p} \leq 0.05)$ were characteristic of these varieties. Pair correlation coefficients between $(\mathrm{a}+\mathrm{b})$ chlorophylls and fruit yield $(r=+0.87)$, and between water content of tissues and fruit bud initiation $(r=+0.97)(\mathrm{p} \leq 0.05)$ indicate that water and temperature regimes influence the yield and fruit bud formation. In the varieties of Prikubanskoe, Fortuna, Soyuz, Rodnichok, the chlorophyll content was more constant during the summer, and the ratio of the sum of chlorophylls to carotenoids is the highest. A positive correlation was found between the carotenoids and the air temperature $(r=+0.91)$ $(\mathrm{p} \leq 0.05)$. Morpho-anatomical structure of the leaf has varietal characteristics and depends on temperature and water availability. In 2012, the varieties exhibited xeromorphic features of leaves to varying degrees, which determined the resistance to drought, and the highest palisade index (1.471.49) was characteristic of the varieties Prikubanskoe, Fortuna, Soyuz, Rodnichok. The obtained results are in line with the field data obtained in the gardens without irrigation. The varieties showed different responses to summer stress factors, i.e. high temperatures and drought. Idared, Earley Mack, Dayton, Ligol plants were "passive" with a reduced water content, high solids, and smaller leaves. The rest varieties maintained high water and pigments in leaves and showed sustainable growth. Thus, Russian apple varieties Prikubanskoe, Fortuna, Soyuz, Rodnichok possess greater ecological plasticity and adaptive reserves compared to the studied introduced foreign varieties. The revealed adaptive features make it possible to involve these varieties in breeding for drought resistance. The applied tests provide accurate assessments of apple drought resistance and can be used in breeding. sistance.

Keywords: apple tree, adaptation, drought resistance, heat resistance, proline, frost re-

\section{Научные собрания \\ МЕЖДУНАРОДНАЯ НАУЧНО-ПРАКТИЧЕСКАЯ КОНФЕРЕНЦИЯ «ИММУНИТЕТ РАСТЕНИЙ К ИНФЕКЦИОННЫМ ЗАБОЛЕВАНИЯМ», посвященная 100-летию монографии Н.И. Вавилова}

(25-28 июня 2019 года, г. Москва)

Тематика:

- Природа иммунитета растений к инфекционным заболеваниям. Факторы иммунитета. Болезни растений и микология. Иммунитет и среда

- Генетика иммунитета. Источники групповой и комплексной устойчивости сельскохозяйственных культур к болезням и вредителям. Специализация и изменчивость патогенов. Преодоление утраты устойчивости у сортов

- Биохимия и молекулярная биология взаимоотношений растений и паразитов. Молекулярная идентификация генов устойчивости

- Иммуногенетическая защита сельскохозяйственных культур. Приобретенный иммунитет и повышение устойчивости растений к болезням и вредителям. Создание устойчивых сортов методами традиционной селекции и биотехнологии

- Роль генетических ресурсов растений в селекции на иммунитет

- Новые средства и методы защиты культур от вредных организмов

- Современные проблемы гербологии и оздоровления почв

- Агроэкологические адаптированные системы интегрированной защиты растений

- Биологическая, химическая защита растений. Цифровая защита растений

- Радиационная защита, радиационная безопасность и радиологический контроль агроэкосистем

Контакты и информация: http://www.vniif.ru 